Marketing i Zarządzanie

nr 4 (45) 2016, s. 203-212

DOI: $10.18276 / \mathrm{miz} .2016 .45-18$

ISSN: 2450-775X | http://wnus.edu.pl/pl/miz/

\title{
Beata Paliś
}

Uniwersytet Ekonomiczny w Krakowie

Wydział Zarządzania

e-mail: beata.palis@interia.pl

\section{Narzędzia marketingowe zagranicznych convention bureaus - studia przypadków}

Kody JEL: Z32, Z33, M31

Słowa kluczowe: przemysł spotkań, marketing terytorialny, marketing przemysłu spotkań, convention bureau

Streszczenie. Celem artykułu jest przedstawienie sposobu realizowania marketingu w obszarze przemysłu spotkań przez zagraniczne biura kongresów (convention bureaus). $\mathrm{W}$ artykule omówiono przedmiotowe zagadnienie w ujęciu teoretycznym. Autorka na wybranych przykładach zagranicznych biur kongresów zaprezentowała stosowane narzędzia marketingu w tej dziedzinie turystyki. Właściwie podejmowane działania w obszarze marketingu przemysłu spotkań wpływają na liczbę spotkań biznesowych w mieście czy regionie. Mogą zatem przynieść wymierne efekty w postaci zwiększenia dochodów destynacji turystycznej.

\section{Wprowadzenie}

Przemysł spotkań rozwija się na świecie coraz bardziej dynamicznie, co wskazuje również na coraz większą profesjonalizację, jeśli chodzi o zarządzanie marketingiem terytorialnym w tej branży. Celem artykułu jest przedstawienie sposobu zarządzania marketingowego w obszarze przemysłu spotkań przez zagraniczne biura kongresów (conventions bureaus). Marketing w obszarze przemysłu spotkań realizowany jest w nieco odmienny sposób niż marketing w ramach innych dziedzin turystyki, widoczne są bowiem różnice w stosowanych narzędziach. W ramach artykułu przedstawiono zagadnienia teoretyczne dotyczące 
przemysłu spotkań, marketingu w przemyśle spotkań, a także narzędzi marketingowych oraz organizacji biur kongresów. Artykuł weryfikuje hipotezę, że odpowiednio realizowany marketing $\mathrm{w}$ tej branży przekłada się na liczbę spotkań biznesowych, a także kreowanie wizerunku destynacji turystyki biznesowej. Hipotezę zweryfikowano na podstawie badania własnego przeprowadzonego wśród zagranicznych biur kongresów. Zastosowano takie narzędzia badawcze jak: kwestionariusz ankietowy, studia przypadków, obserwację uczestniczącą oraz analizę stron internetowych.

\section{Marketing terytorialny w ujęciu teoretycznym}

Omawiając przedmiotowe zagadnienie warto przedstawić podstawowe definicje dotyczące marketingu terytorialnego. Należy podkreślić, że biura kongresów (conventions bureaus) w Polsce i na świecie zajmują się właśnie tym rodzajem marketingu w zakresie przemysłu spotkań, inaczej turystyki biznesowej. Marketing terytorialny określany jest w literaturze m.in. jako proces społeczny i kierowniczy, który inicjują podmioty komunalne, po to, aby wykreować wymianę wartości z ich partnerami (Kotler, 1994, s. 6). Należy podkreślić, że to właśnie w koncepcjach zarządzania marketingiem terytorialnym należy poszukiwać źródeł tego rodzaju marketingu. Władze publiczne, które dostarczają usługi publiczne, wspierają konkurencyjność przedsiębiorstw zlokalizowanych na ich terenie, a także konkurują z innymi o różne cele i interesy własnej społeczności (Szromnik, 2007, s. 115). Celem tych działań jest wpływanie na opinie, postawy i sposoby zachowania się zewnętrznych i wewnętrznych grup zainteresowanych klientów przez dobór i kształtowanie właściwego zestawu środków i instrumentów. Do celów zorientowanych na adresatów zewnętrznych można zaliczyć kształtowanie oferty m.in. turystycznej, efektywne i skuteczne komunikowanie się z zainteresowanymi podmiotami, kształtowanie osobowości, tożsamości i atrakcyjnego wizerunku danego obszaru (Szromnik, 2007, s. 22-24).

Jak wskazuje M. Raftowicz-Filipkiewicz: „skupiając się na płaszczyźnie miejsca (jako kraju, regionu, gminy czy miasta), możemy uznać, że współcześnie jest ono traktowane jako specyficzny składnik aktywów gospodarczych. Wynika to $\mathrm{z}$ przyjętej koncepcji marketingu terytorialnego (marketing places), która uznaje, że każde miejsce konkuruje z innymi na polu ekonomicznych atutów, promując swój wizerunek, kulturę i historię, potencjał inwestycyjny czy turystyczny, a działania na rzecz marketingu miejsc są niezbędnym elementem wspomagającym rozwój jednostek terytorialnych, a tym samym decydującym o ich konkurencyjności i atrakcyjności" (Raftowicz-Filipkiewicz, 2013, s. 57). Autorka dodaje także, że: ,przedmiotem marketingu terytorialnego są walory zarówno materialne, jak i niematerialne miejsc, tj. infrastruktura, ludzie, atrakcje turystyczne i przyrodnicze, potencjał gospodarczy i kulturowy, marka terytorium, wizerunek i inne" (Raftowicz-Filipkiewicz, 2013, s. 59). Według V. Gollaina zaś 
podstawowym celem marketingu terytorialnego są działania na rzecz uatrakcyjnienia miejsca lub podniesienia jego wartości. Autor uważa, że działania te powinny być prowadzone przez agencje rozwoju regionalnego występujące w imieniu władz publicznych (Gollain, Guide du marketing. Réussir son marketing territorial en 10 étapes, 2010, za: Raftowicz-Filipkiewicz, 2013, s. 59). Według F. Hatema natomiast idea marketingu terytorialnego to przede wszystkim wspieranie, a także tworzenie korzystnych i długofalowych relacji gospodarczych między przedstawicielami biznesu, mieszkańcami oraz władzami terytorialnymi (Hatem, Le marketing territorial: principes, méthodes et pratiques, 2007, za: Raftowicz-Filipkiewicz, 2013, s. 59). Koncepcja marketingu terytorialnego w obszarze przemysłu spotkań wpisuje się w tę definicję, gdyż realizacja tego właśnie marketingu polega $\mathrm{w}$ głównej mierze na kreowaniu powiązań gospodarczych między branżą tej dziedziny gospodarki turystycznej, ale także mieszkańcami czy władzami terytorialnymi. Duże znaczenie ma również powiązanie z przedstawicielami uczelni wyższych, których działania, polegające na przyciąganiu zwłaszcza międzynarodowych kongresów czy konferencji, przyczyniają się do kreowania marki destynacji turystyki biznesowej. W marketingu przemysłu spotkań chodzi właśnie o wykreowanie marki i wizerunku miejsca recepcji przemysłu spotkań.

A. Niezgoda zauważa, że w literaturze opracowania dotyczące marketingu w turystyce dotyczą głównie wykorzystania narzędzi marketingu, a przede wszystkim koncentrują się na koncepcji 4P (product, price, promotion, place) (Niezgoda, 2011, s. 394). Marketing przemysłu spotkań także koncentruje się na używaniu tych elementów składowych narzędzi marketingu terytorialnego.

\section{Przemysł spotkań - podstawowe definicje}

Przemysł spotkań to jeden z najbardziej popularnych i dochodowych oraz najszybciej rozwijających się obecnie sektorów turystyki. Dawniej stosowano głównie określenie turystyka biznesowa. Pojęcie to wyjaśniane jest na wiele sposobów (Paliś, 2015, s. 56). Jeden z nurtów definicyjnych - behawioralny - definiuje turystykę biznesową na podstawie charakteru aktywności podmiotów interakcji. Jego zwolennikiem jest R. Davidson, który utożsamia ten rodzaj turystyki $\mathrm{z}$ osobami podróżującymi $\mathrm{w}$ celach ściśle związanych $\mathrm{z}$ interesami i ich pracą zawodową (Davidson, Cope, 2003, s. 3). S. Medlik turystykę biznesową rozumie natomiast jako podróże odbywane przez pracowników i inne osoby w ramach ich pracy (Medlik, 1995, s. 54). Drugi z nurtów, opisowo-wyliczający, wskazuje na taki sposób rozumienia turystyki biznesowej, który obejmuje wszelkie podróże odbywane przez pracowników i inne osoby w ramach ich pracy, tj. udział w spotkaniach, takich jak: konferencje, zjazdy, kongresy, szkolenia, seminaria, targi, wystawy oraz imprezy motywacyjne (Metodologia badań $i$ badania pilotażowe turystyki biznesowej, Instytut Turystyki, 2003, s. 12, za: Berbeka, Borodako, Niemczyk, Seweryn, 2013, s. 7). 
K. Celuch wskazuje na określenie tego zjawiska jako „branża spotkań, podróży motywacyjnych, konwencji i wystaw (Meetings, Incentives, Conferences and Exhibitions - MICE)" (Celuch, 2015, s. 18-28). Pisze on także, że omawiana dziedzina najczęściej była określana jako MICE. Jednak sfomułowanie to nie obejmowało branży całościowo. Organizacja UNWTO używa zamiennie sfomułowań: „przemysł spotkań” lub „międzynarodowy przemysł spotkań. Terminy te odnoszą się do organizacji, promocji, sprzedaży, a także dostarczania usług dla spotkań biznesowych, podróży motywacyjnych, seminariów, kongresów i konferencji, wydarzeń biznesowych, wystaw i targów, jak również wizyt technicznych. UNWTO zaproponowało ponadto stworzenie nowej kategorii definiującej przemysł spotkań przez dodatkową klasę „Organizatorów konwencji i targów” (Convention and trade show organizers). Według UNWTO przemysł ten obejmuje: organizację, promocję, a także zarządzanie wydarzeniami, tj. targami, konwencjami, kongresami i konferencjami. Po szerokich konsultacjach branżowych ostatecznie zaproponowano jednak termin ,przemysł spotkań” (meetings industry), gdyż głównym elementem każdego spotkania czy wydarzenia biznesowego jest spotkanie ludzi. Ponadto definicja ta określa dokładnie klientów, takich jak: stowarzyszenia, korporacje czy administracja rządowa oraz dotyczy podróży motywacyjnych (UNWTO, Measuring the economic importance of the meetings industry. developing a tourism satellite account, 2006, s. 4, za: Celuch, 2015, s. 20).

Pojęcie „przemysł spotkan” odnosi się do dynamicznie rozwijającej się branży obejmującej wszystkie wyżej wskazane wydarzenia (Wróblewski, 2014, s. 13). W praktyce marketing w obszarze przemysłu spotkań realizowany jest w nieco odmienny sposób przez wykorzystanie stosownych narzędzi marketingowych. Chociaż są one podobne do narzędzi stosowanych w marketingu innych dziedzin turystyki, to jednak różni się sposób dotarcia do właściwych adresatów. Szczególną rolę odgrywają media branżowe, a także panujące w tej branży standardy, które często są powielane i wdrażane.

\section{Marketing zagranicznych convention bureaus - badania wlasne}

W branży przemysłu spotkań działa wiele podmiotów. Do kluczowych należą biura kongresów (convention bureaus). Biura te, działające w różnych strukturach miast, zajmują się promocją miejsca recepcji turystycznej jako atrakcyjnej destynacji dla organizacji spotkań biznesowych. Zajmują się przede wszystkim marketingiem terytorialnym obszarów geograficznych w zakresie przemysłu spotkań. $Z$ punktu widzenia zarządzania przemysłem spotkań, obszar recepcji turystycznej to przede wszystkim strefa preferencji organizatorów turystyki biznesowej i turystów biznesowych, stanowiąca niepowtarzalną całość, która jest administrowana i zarządzana oraz podlega także pewnym zbliżonym uwarunkowaniom (społeczno-kulturowym, przyrodniczym i gospodarczym) planowania i marketingu turystyki biznesowej (Crouch, Ritchie, 1999, s. 137-152). 
W maju 2016 roku autorka przeprowadziła badania z wykorzystaniem takich narzędzi jak: kwestionariusz ankietowy, wywiad bezpośredni oraz przeanalizowała strony internetowe. Ważnym elementem prowadzonych badań była także obserwacja uczestnicząca. Badania miały na celu potwierdzenie tezy, że właściwie realizowane działania marketingowe w branży przemysłu spotkań przekładają się na liczbę spotkań biznesowych, a także kreowanie wizerunku destynacji turystyki biznesowej ${ }^{1}$. Celem badań było także zidentyfikowanie prowadzonych działań i narzędzi marketingowych przez zagraniczne biura kongresów. Badaniem objęto 10 podmiotów z różnych kontynentów. Kwestionariusz ankietowy skierowano do podmiotów z Europy, Azji, Australii i USA. Pozyskano cztery kwestionariusze, co stanowi 40\% badanej populacji. Działania pozostałej części podmiotów zweryfikowano przez analizę stron internetowych. Porównano narzędzia marketingowe stosowane przez biura kongresów (convention bureaus) w Europie i na innych kontynentach wskazując na różnice i podobieństwa w tym zakresie.

W tabeli 1 zaprezentowano wyniki badań ankietowych przeprowadzonych wśród Biur Kongresów z Europy, tj. Vienna Convention Bureau (Austria), Lyon Convention Bureau (Francja), Amsterdam Marketing (Holandia), a także jednego Biura Kongresów z Australii, tj. informacje na temat ich działalności, stosowanych narzędzi marketingowych oraz wielkości budżetu na działania marketingowe.

Tabela 1

Narzędzia marketingowe wybranych zagranicznych biur kongresów

\begin{tabular}{|c|c|c|c|c|}
\hline Działanie & $\begin{array}{c}\text { Vienna Convention } \\
\text { Bureau }\end{array}$ & $\begin{array}{l}\text { Lyon Convention } \\
\text { Bureau }\end{array}$ & $\begin{array}{l}\text { Amsterdam } \\
\text { Marketing }\end{array}$ & $\begin{array}{c}\text { Convention Bureau } \\
\text { z dużego miasta } \\
\text { w Australii }\end{array}$ \\
\hline $\begin{array}{l}\text { Strategia } \\
\text { marketin- } \\
\text { gowa }\end{array}$ & $\begin{array}{l}\text { mają strategię marke- } \\
\text { tingową na } 2016 \text { r. } \\
\text { i inne lata, ale nie zo- } \\
\text { stała opracowana we } \\
\text { współpracy z branżą } \\
\text { przemysłu spotkań }\end{array}$ & $\begin{array}{l}\text { mają strategię na } \\
\text { lata 2016-2018, } \\
\text { która została opra- } \\
\text { cowana we wspó-- } \\
\text { pracy z branżą prze- } \\
\text { mysłu spotkań }\end{array}$ & $\begin{array}{l}\text { mają długofa- } \\
\text { lową strategię na } \\
10 \text { lat, która zo- } \\
\text { stała opracowana } \\
\text { we współpracy } \\
\text { z branżą przemy- } \\
\text { słu spotkań }\end{array}$ & $\begin{array}{l}\text { mają } 3 \text { letni biznes plan, } \\
\text { a także towarzyszącą stra- } \\
\text { tegię marketingową; stra- } \\
\text { tegia długookresowa jest } \\
\text { również opracowywana; } \\
\text { spostrzeżenia i trendy, } \\
\text { o których dowiadują się } \\
\text { na bieżąco są również } \\
\text { brane pod uwagę dla kie- } \\
\text { runku, który obejmują } \\
\text { w zasięgu rocznym }\end{array}$ \\
\hline $\begin{array}{l}\text { Narzędzia } \\
\text { marketin- } \\
\text { gowe }\end{array}$ & $\begin{array}{l}\text { - udział w targach } \\
\text { branżowych IMEX } \\
\text { Frankfurt, IMEX Las } \\
\text { Vegas, Meeting } \\
\text { Show UK, IBTM } \\
\text { Barcelona, ACEfor- } \\
\text { MICE Istanbuł }\end{array}$ & $\begin{array}{l}\text { - udział w targach } \\
\text { branżowych IBTM, } \\
\text { IMEX, Meeting } \\
\text { Show, REUNIR, } \\
\text { Heavent i innych } \\
\text { wydarzeniach orga- } \\
\text { nizowanych z Atout } \\
\text { France }\end{array}$ & $\begin{array}{l}\text { - udział w tar- } \\
\text { gach branżowych } \\
\text { - organizują wi- } \\
\text { zyty studyjne dla } \\
\text { firm PCO (Pro- } \\
\text { fessional Con- } \\
\text { gress Organizers) }\end{array}$ & $\begin{array}{l}\text { - udział w krajowych i za- } \\
\text { granicznych targach bran- } \\
\text { żowych tj. IMEX Europe } \\
\text { i IMEX USA, AIME, } \\
\text { IBTM, ATE; udział w mi- } \\
\text { sjach gospodarczych obok } \\
\text { rządowych interesariuszy }\end{array}$ \\
\hline
\end{tabular}

${ }^{1}$ Wizerunek destynacji turystyki biznesowej to wrażenie odbiorów, że miejsce jest atrakcyjne dla organizacji różnego rodzaju spotkań biznesowych. 


\begin{tabular}{|c|c|c|c|c|}
\hline & $\begin{array}{l}\text { - organizują grupowe } \\
\text { wizyty studyjne dla } \\
\text { przedstawicieli agen- } \\
\text { cji korporacyjnych, } \\
\text { dla przedstawicieli } \\
\text { stowarzyszeń organi- } \\
\text { zowane są indywidu- } \\
\text { alne wizyty studyjne } \\
\text { - mają profil w me- } \\
\text { diach społecznościo- } \\
\text { wych LinkedIn } \\
\text { i XING } \\
\text { - zamieszczają re- } \\
\text { klamy w następują- } \\
\text { cych mediach bran- } \\
\text { żowych: AMI, } \\
\text { M\&IT, Tagungswirt- } \\
\text { schaft,, CIM, CMW, } \\
\text { Meetings Internatio- } \\
\text { nal, Convene, Suc- } \\
\text { cessful Meetings, na- } \\
\text { ukowych } \\
\text { - są członkami sto- } \\
\text { warzyszeń branżo- } \\
\text { wych: ICCA, MPI, } \\
\text { PCMA, DMAI, wy- } \\
\text { korzystują bazę da- } \\
\text { nych ICCA, wszyst- } \\
\text { kie inne dla pozyski- } \\
\text { wania kontaktów, } \\
\text { a także wiedzy } \\
\text { - współpracują } \\
\text { z przedstawicielami } \\
\text { uczelni wyższych } \\
\text { w celu pozyskiwania } \\
\text { kongresów i konfe- } \\
\text { rencji } \\
\text { - prowadzą badania } \\
\text { rynku przemysłu spo- } \\
\text { tkań, a także promują } \\
\text { ich wyniki przez } \\
\text { opracowanie Mee- } \\
\text { ting Industry Report }\end{array}$ & $\begin{array}{l}\text { - organizują wizyty } \\
\text { studyjne dla organi- } \\
\text { zatorów turystyki } \\
\text { biznesowej; } \\
\text { w } 2015 \text { r. odwie- } \\
\text { dziło ich } 148 \text { osób } \\
\text { - wysyłają new- } \\
\text { slettery } 4 \text { razy } \\
\text { w roku } \\
\text { - udział w stowa- } \\
\text { rzyszeniu branżo- } \\
\text { wym ICCA } \\
\text { - dystrybuują mate- } \\
\text { riały promocyjne } \\
\text { elektroniczne, pa- } \\
\text { pierowe, w czasie } \\
\text { targów i konferencji }\end{array}$ & $\begin{array}{l}\text { i DMC(Destina- } \\
\text { tion Management } \\
\text { Company) 3-10 } \\
\text { razy w roku } \\
\text { - profil w me- } \\
\text { diach społeczno- } \\
\text { ściowych Face- } \\
\text { book, LinkedIn, } \\
\text { Instagram i inne } \\
\text { - nie płacą za re- } \\
\text { klamy prasowe } \\
\text { - udział w sto- } \\
\text { warzyszeniach } \\
\text { branżowych } \\
\text { ICCA i UIA } \\
\text { - bezpośrednie } \\
\text { kontakty z part- } \\
\text { nerami z branży } \\
\text { przemysłu spo- } \\
\text { tkań } \\
\text { - mają na stronie } \\
\text { internetowej ka- } \\
\text { lendarz wyda- } \\
\text { rzeń bizneso- } \\
\text { wych } \\
\text { - dystrybuują } \\
\text { materiały promo- } \\
\text { cyjne w wersji } \\
\text { papierowej, elek- } \\
\text { tronicznej oraz } \\
\text { w czasie targów } \\
\text { i spotkań bizne- } \\
\text { sowych, } \\
\text { - wydają roczną } \\
\text { publikację doty- } \\
\text { czącą badań } \\
\text { przemysłu spo- } \\
\text { tkań - Key Figu- } \\
\text { res Amsterdam } \\
\text { and Congress } \\
\text { Destination, } \\
\text { którą uznano za } \\
\text { najlepszą w Eu- } \\
\text { ropie i prawdo- } \\
\text { podobnie na } \\
\text { świecie i nagro- } \\
\text { dzono przez } \\
\text { UNWTO }\end{array}$ & $\begin{array}{l}\text { - organizacja wizyt stu- } \\
\text { dyjnych dla firm PCO, } \\
\text { DMC i mediów branżo- } \\
\text { wych w zależności od po- } \\
\text { trzeb i wymagań klientów } \\
\text { - profil w mediach spo- } \\
\text { łecznościowych: Twitter, } \\
\text { LinkedIn, Facebook, We- } \\
\text { ibo i WeChat } \\
\text { - reklama w mediach } \\
\text { branżowych zarówno dru- } \\
\text { kowanych jak i online } \\
\text { - członkostwo w ICCA } \\
\text { - newslettery dla klien- } \\
\text { tów, większość z nich 2-3 } \\
\text { razy w roku } \\
\text { - sponsorują konferencje, } \\
\text { a także realizują promocję } \\
\text { w czasie konferencji } \\
\text { - promują destynację } \\
\text { w czasie konferencji, } \\
\text { które po raz kolejny mają } \\
\text { odbyć się w ich mieście } \\
\text { - ściśle współpracują } \\
\text { z Ambasadorami Kongre- } \\
\text { sów, którymi są głównie } \\
\text { pracownicy wyższych } \\
\text { uczelni, pomagają im } \\
\text { w promocji miejsca jako } \\
\text { silnej destynacji turystyki } \\
\text { biznesowej i w przyciąga- } \\
\text { niu zarówno krajowych } \\
\text { jak i zagranicznych wyda- } \\
\text { rzeń } \\
\text { - realizują Program Am- } \\
\text { basadorów Kongresów, } \\
\text { mają film reklamowy } \\
\text { z ich udziałem } \\
\text { - publikują i dystrybuują } \\
\text { materiały promocyjne } \\
\text { w wersji elektronicznej, } \\
\text { papierowej oraz w czasie } \\
\text { targów branżowych i spo- } \\
\text { tkań } \\
\text { - prowadzą badania prze- } \\
\text { mysłu spotkań i promują } \\
\text { ich rezultaty, ich głównym } \\
\text { badanerem jest uniwersytet, które pomagająą im } \\
\text { lepiej zrozumieć świat } \\
\text { przemysłu spotkań }\end{array}$ \\
\hline $\begin{array}{l}\text { Okres dzia- } \\
\text { łalności }\end{array}$ & ponad 20 lat & ponad 20 lat & ponad 20 lat & ponad 20 lat \\
\hline $\begin{array}{l}\text { Roczny bu- } \\
\text { dżet na dzia- } \\
\text { lania marke- } \\
\text { tingowe lub } \\
\text { promocyjne } \\
\text { w latach } \\
\text { 2014-2016 }\end{array}$ & $\begin{array}{l}\text { na kampanię rekla- } \\
\text { mową w } 2014 \text { i } 2015 \\
\text { r. wydano po } 120 \text { tys. } \\
\text { euro; w } 2016 \text { r. na } \\
\text { działania marketin- } \\
\text { gowe zaplanowano } \\
1,900 \text { tys. euro }\end{array}$ & $\begin{array}{l}\text { Na działania pro- } \\
\text { mocyjne wydano w } \\
2014 \text { r. }-615 \text { tys. } \\
\text { euro, w } 2015 \text { r.- } \\
548 \text { tys. euro, } \\
\text { a w } 2016 \text { r. - } \\
500 \text { tys. euro }\end{array}$ & $\begin{array}{l}1 \text { mln euro na } \\
\text { każdy rok }\end{array}$ & nie podano informacji \\
\hline
\end{tabular}

Źródło: opracowanie i tłumaczenie własne na podstawie przeprowadzonych badań ankietowych. 
Porównując dane zestawione w tabeli 1, a także analizując strony internetowe innych sześciu zaprezentowanych convention bureaus na świecie należy stwierdzić, że stosowane narzędzia marketingowe w marketingu terytorialnym przemysłu spotkań są podobne. Do głównych narzędzi marketingowych stosowanych przez convention bureaus zatem należą:

- udział w targach branżowych; wiodące to: IMEX w Frankfurcie, IMEX w Las Vegas i IBTM w Barcelonie, w których udział biorą ankietowane biura, dodatkowo uczestniczą one także w innych wydarzeniach,

- organizacja wizyt studyjnych dla firm PCO, DMC oraz przedstawicieli stowarzyszeń branżowych,

- publikacja i dystrybucja materiałów promocyjnych,

- prowadzenie badań rynku przemysłu spotkań i promocja ich wyników,

- realizacja Programu Ambasadorów Kongresów i współpraca z przedstawicielami uczelni wyższych w celu przyciągania kongresów i konferencji, a także wzmacniania marki destynacji w obszarze przemysłu spotkań,

- reklama w mediach branżowych,

- prowadzenie kalendarza wydarzeń online,

- prowadzenie profili w różnych mediach społecznościowych.

W marketingu przemysłu spotkań funkcjonuje jeszcze wiele innych narzędzi. Szczególnie ważne to: np. tworzenie systemów rekomendacji firm PCO (Profesjonalnych Organizatorów Kongresów) czy Organizatorów Podróży Motywacyjnych, tworzenie oferty oraz promocja miejsc konferencyjnych i kongresowych, bazy noclegowej, miejsc unikatowych, promocja oferty cenowej tych miejsc, tworzenie i promowanie oferty podróży motywacyjnych.

Podsumowując wyniki badań, należy uznać, że w działalności tej szczególne znaczenie ma dysponowanie długofalową strategią działań marketingowych opracowaną we współpracy z branżą przemysłu spotkań. Convention bureaus, które wzięły udział w badaniu mają takie strategie, jednak obejmują one różne okresy. Nie w każdym też przypadku strategia została opracowana we współpracy z branżą przemysłu spotkań, a w tej branży działania w partnerstwie $\mathrm{z}$ innymi podmiotami mają kluczowe znaczenie, gdyż marketing destynacji dotyczy właśnie owych podmiotów funkcjonujących na tym rynku i tworzących ofertę destynacji dla przemysłu spotkań.

Odpowiadając na pytanie w wywiadzie bezpośrednim, co jest najważniejszym elementem w marketingu biur kongresów (convention bureau), Dyrektorzy Biur Kongresów z Wiednia i Lionu stwierdzili²:

1. „Najważniejszym elementem w marketingu convention bureau jest bycie niezależnym od wszelkich wpływów, takich jak polityka czy inni interesariusze itp.; stuprocentowa koncentracja na potrzebach klienta jest doskonałą

\footnotetext{
${ }^{2}$ Tłumaczenie wypowiedzi B. Paliś.
} 
podstawą, aby odnieść sukces jako biuro, ale także jako miejsce docelowe" (Christian Mutschlechner - dyrektor Vienna Convention Bureau).

2. „Działania marketingowe convention bureau są uzależnione od oferty strukturalnej miejsca docelowego, tj. międzynarodowych połączeń lotniczych, wystarczającej bazy hotelowej czy konferencyjnej, rozgłosu o destynacji. Jeśli mówimy o priorytetach dla convention bureau to jest to ubieganie się o międzynarodowe kongresy" (Valérie Ducaud - dyrektor Lyon Convention Bureau).

Dyrektorzy w swoich wypowiedziach zwrócili uwagę na bardzo ważne kwestie, że: convention bureau powinny w swoich strukturach organizacyjnych być niezależne od wpływów politycznych oraz, że ich działania są zdeterminowane rozwojem infrastruktury turystycznej. Wskazano także na najważniejsze i główne narzędzie marketingowe, jakim jest opracowywanie ofert na organizację kongresów i konferencji, a przez to ich przyciąganie.

Według R. Davidsona zgodnie ze współczesnymi trendami „,w promocji, zarówno poszczególnych obiektów, jak i destynacji (miast i regionów), bardzo często wykorzystywana jest siła miejscowej gospodarki. Dobrym przykładem są Niemcy, w których poszczególne gałęzie przemysłu zostały «przypisane» konkretnym regionom. Dzięki temu niektóre części kraju kojarzą się z energią, inne z przemysłem chemicznym, jeszcze inne z nowoczesnymi technologiami. Taki zabieg ma na celu zainteresowanie korporacyjnych i stowarzyszeniowych meeting plannerów miejscami, w których za względu na charakter i specyfikę prowadzonej przez nich działalności przygotowanie imprez może okazać się dla nich szczególnie korzystne" (Davidson, 2016).

Dodatkowo przeanalizowano również strony internetowe conventions bureaus następujących destynacji: Chicago (www.choosechicago.com/meeting-professionals/), Detroit (http://visitdetroit.com), Nowy Jork (www.newyorkmeetings.com), Tokio (http://businesseventstokyo.org), Singapur (www.yoursingapore.com/mice/en/about-us/about-secb.html), Toronto (http://meetings.seetorontonow.com/). Stosowane przez biura narzędzia marketingowe są podobne do wcześniej wymienionych. Warto jednak zwrócić uwagę na dodatkowe, które oferują niektóre z analizowanych convention bureaus, czyli: promocja zielonych wydarzeń, promocja spotkań przez wykorzystanie bezpłatnych narzędzi - pakietów promocyjnych, możliwość bezpłatnego korzystania z materiałów promocyjnych czy zdjęć, pomoc w zorganizowaniu transportu wykładowców, pomoc w pozyskaniu uczestników konferencji, dodatkowe public relations dla wydarzenia - pomoc w nagłośnieniu wydarzenia przez współpracę z mediami w całym kraju, udostępnienie wolontariuszy, coroczne tworzenie planów marketingowych we współpracy z partnerami, program partnerski mający na celu stworzenie sieci partnerów, wspierających realizację działań marketingowych na rzecz promocji destynacji jako atrakcyjnego miejsca dla turystyki i wydarzeń biznesowych, lista 
partnerów do współpracy PCO i DMC, specjalna oferta dla wydarzeń korporacyjnych, udział w innych targach niż wcześniej wymienione, np. IT \& CM China, promocja na stronie internetowej studiów przypadków konkretnych wydarzeń, stoisko promocyjne na lotnisku i wiele innych.

Według najnowszego Międzynarodowego rankingu Miasta ICCA Statistics Report 2015, który obejmuje ponad 400 podmiotów z całego świata niektóre omawianych miejsc znalazły się w czołówce z największą liczbą spotkań biznesowych, według definicji ICCA $(\text { About ... })^{3}$ : według rankingu międzynarodowego w miastach: Wiedeń - 4. pozycja z 178 spotkaniami, Amsterdam - 12. pozycja z 120 spotkaniami, Singapur - 7. pozycja ze 156 spotkaniami; ranking międzynarodowy: liczba spotkań w krajach: USA - 1. pozycja z 925 spotkaniami, Austria - 14. pozycja z 258 spotkaniami, Francja - 5. pozycja z 522 spotkaniami, Holandia - 9. pozycja z 333 spotkaniami, Kanada - 10. pozycja z 308 spotkaniami, Australia - 1.5 pozycja z 247 spotkaniami (About...).

\section{Podsumowanie}

Głównym celem działalności biur kongresów na świecie jest prowadzenie działań marketingowych po to, aby wykreować wizerunek destynacji jako atrakcyjnego miejsca do organizacji spotkań biznesowych. W działalności tej chodzi jednak przede wszystkim o przyciąganie do kraju, regionu czy miasta jak największej liczby spotkań biznesowych, na co przekłada się umiejętne stosowanie narzędzi marketingowych. Zagraniczne biura kongresów (convention bureaus) stosują podobne narzędzia marketingowe służące temu samemu celowi. Niektóre z nich wprowadzają także dodatkowe elementy marketingu, aby wyróżnić się na tle innych destynacji i być bardziej konkurencyjne. Najważniejszym narzędziem działalności convention bureaus jest ubieganie się o kongresy i konferencje, a działania te w obszarze marketingu terytorialnego są w dużej mierze zdeterminowane tym, co oferuje miejsce docelowe.

\section{Bibliografia}

About ICCA (26.05.2016). Pobrano z: www.iccaworld.com/abouticca.cfm.

Berbeka, J, Borodako, K., Niemczyk, A., Seweryn, R. (2013). Przemyst spotkań w Krakowie oraz Matopolsce w 2012 roku. Kraków: Fundacja Uniwersytetu Ekonomicznego w Krakowie.

Celuch, K. (2015). Międzynarodowy przemysł spotkań jako przykład działań na rzecz intensyfikacji wykorzystania przestrzeni turystycznej. Zeszyty Naukowe Uczelni Vistula, 40, 18-28.

Crouch, G.I., Ritchie, J.R.B. (1999). Tourism, competitiveness, and societal prosperity. Journal of Business Research, 44 (1), 137-152.

\footnotetext{
${ }^{3}$ ICCA - the International Congress and Convention Association, Międzynarodowe Stowarzyszenie Kongresów i Konferencji założone w 1963 r. zrzeszające 1061 członków z 95 krajów z główną siedzibą w Amsterdamie; spotkania według raportu ICCA - odbywają się regularnie i zamiennie w co najmniej 3 różnych krajach, a także uczestniczy w nich minimum 50 osób). (About ...).
} 
Davidson, R. (24.05.2016). Współczesne trendy w przemyśle spotkań. Pobrano z: www.eventmapa.pl/gosc/249/rob-davidson\#.V9k-mK1Tb-F.

Davidson, R., Cope, B. (2003), Turystyka biznesowa. Konferencje, podróże motywacyjne, wystawy, turystyka korporacyjna. Warszawa: Polska Organizacja Turystyczna.

http://businesseventstokyo.org/ (26.05.2016).

http://meetings.seetorontonow.com/ (26.05.2016).

http://visitdetroit.com/ (26.05.2016).

Kotler, Ph. (1994). Marketing. Analiza, planowanie, wdrażanie i kontrola. Warszawa: Gebethner \& S-ka.

Medlik, S. (1995). Leksykon podróży, turystyki i hotelarstwa. Warszawa: Wydawnictwo Naukowe PWN.

Niezgoda, A. (2011). Możliwości wykorzystania marketingu miejsc na obszarze recepcji turystycznej - istota i problemy. Zeszyty Naukowe Uniwersytetu Szczecińskiego, 663, Ekonomiczne Problemy Ustug, 75, 393-406.

Paliś, B. (2015). Przemysł spotkań a ewolucja wizerunku miasta na przykładzie Krakowa. Zeszyty Naukowe Uniwersytetu Szczecińskiego, 867, Problemy Zarządzania, Finansów i Marketingu, 40, 55-69.

Szromnik, A. (2007). Marketing terytorialny. Miasto i region na rynku. Kraków: Wolters Kluwer Polska.

Raftowicz-Filipkiewicz, M. (2013). Marketing terytorialny jako narzędzie budowania przewagi konkurencyjnej gmin Doliny Baryczy. Nauki o Zarządzaniu. Management Sciences, 1 (14), $57-68$.

Wróblewski, S. (red.). (2014). Stowarzyszenia profesjonalne w tworzeniu przemystu spotkań w Polsce. Warszawa: Stowarzyszenie „Konferencje i Kongresy w Polsce”.

www.choosechicago.com/meeting-professionals/ (26.05.2016).

www.newyorkmeetings.com/cvb/new-york-city/ (26.05.2016).

www.yoursingapore.com/mice/en/about-us/about-secb.html (26.05.2016).

\section{Marketing Tools Used by Foreign Convention Bureaus - Case Studies}

Keywords: meetings industry, territorial marketing, meetings industry marketing, convention bureau

Summary. The aim of the article is to provide a method for implementing marketing in the area of the meetings industry by foreign convention bureaus. At the beginning the author discusses the subject issue in theoretical terms. The author selects examples of foreign convention bureaus and presents the tools used in marketing of the meetings industry. The proper activities, that are taken in the area of the meetings industry marketing, have an impact on the number of business meetings in the city or region. So, these actions can bring tangible results in terms of increased revenues of the tourist destination.

Translated by Beata Paliś

\section{Cytowanie}

Paliś, B. (2016). Narzędzia marketingowe zagranicznych convention bureaus - studia przypadków. Marketing i Zarzadzanie, 4 (45), 203-212. 